\title{
Citizenship Perceptions of University Students
}

\author{
Mehmet Fatih Yigit ${ }^{1}$ \\ ${ }^{1}$ Suleyman Sah University, Turkey \\ Correspondence: Mehmet Fatih Yigit, Suleyman Sah University, Turkey
}

Received: February 3, 2016

Accepted: February 15, 2016

Online Published: February 16, 2016

doi:10.5430/ijhe.v5n2p40

URL: http://dx.doi.org/10.5430/ijhe.v5n2p40

\begin{abstract}
Citizenship has become one of the important topics discussed in especially developed countries by policy makers and various stakeholders in recent years. Some important reasons behind it are the political, economic and social uneasiness throughout the world in both collectivistic and individualistic societies. The current study aims at looking at the citizenship perception among university students in one of those collectivistic countries. The participants answered the question 'what does citizenship mean for you?' and the data was analyzed by giving descriptive statistics using the quantitative data analysis software, SPSS. The value items given as choices to the students were; equality, freedom, social order, national security, a world at peace, respect for tradition, respect for privacy, social justice, independent, protecting the environment, loyalty, obedient, helpful, and responsible. The participants were categorized in two different faculties which were faculty of humanities and social sciences and faculty of management and administrative sciences. The results show that the students from faculty of humanities and social sciences have tendency towards values represented in individualistic societies while defining citizenship. On the other hand, students of faculty of management and administrative sciences showed greater tendency towards the values represented in collectivistic countries. Another finding of the study was that females highly prioritized all value items compared to male participants. Turkey is considered to be a collectivistic country however the results show that majority of the participants prioritize values represented in individualistic nations. Further studies need to be conducted in order to find out whether there has been a shift from being a collectivistic society or not.
\end{abstract}

Keywords: Citizenship, Value, Perception, Higher education

\section{Introduction}

The term 'citizenship' has gained more importance in today's world due to the political, economical and social problems developing and developed countries have experienced. The political instabilities, economic problems and social uneasiness are so common that it becomes a necessity to implement relevant policies in order to overcome the negative outcomes of those problems since they have adverse effects on economic growth (Aisen \& Veiga, 2013). Besides implementing those relevant policies in governmental level, a new way of defining 'citizenship' is crucial for a peaceful atmosphere. It is important because human migrations have accelerated throughout the world that makes almost all states multicultural in demographic composition (Heater, 2013). In such multicultural settings, it becomes more important to define 'citizenship' in order to have the unity in state level.

In such multicultural states, certain social institutions play crucial roles in shaping the societies (Aydin, 2013; Aydin \& Tonbuloglu, 2014). Educational institutions are among those that have great influence on members of societies regarding how citizenship is perceived. In this sense, primary schools have the most influential effects on establishing citizenship perceptions but universities are also important institutions that help societies to establish and enrich the notion of 'citizenship' (Kaya, 2015). Hicks (2006) has identified universities as institutions that should help students to gain the ability of communication, critical thinking, living in a global and diverse society and moral reasoning. Preparation for citizenship is also mentioned among the duties of universities.

The perception of citizenship includes some values and beliefs that are accepted as being 'true' in societies. It can be claimed that not everything is equally valuable for all societies. The level of importance might show differences or even in some societies, some perceptions that are regarded as 'value' are totally meaningless. In this sense, defining universal values are criticized by several researchers (Fowers \& Richardson, 1996; Scott, 2000). However, there have been some social scientists who have tried to bring an explanation to the term 'value' that makes it possible to think globally on some items regarded as 'value'. Rokeach (1968, p. 167) have identified value as an "enduring belief that a specific mode of conduct or end-state of existence is personally and socially preferable to alternative 
modes of conduct or end-states of existence". Bond (1983) has identified values as something worth having while Barrett (1961) defines values as something that are important in behavior. Values are told to be demonstrating attractive actions that direct personal behaviors (Feather, 1995; Karatas \& Oral, 2015). Values are so important that they have influence on predicting the level of social contact of a person with others who do not live in his/her community (Sagiv \& Schwartz, 1995).

The purpose of this study is to find out how university students perceive the term 'citizenship'. In order to make it more clear for the participants, several values included in the value survey designed by Schwartz (1992) were extracted and given as the choices to the question 'what does citizenship mean for you?'. The Value Survey designed by Schwartz (1992) includes 56 single values that are categorized under eleven distinct motivational types of values which are; Power, Achievement, Hedonism, Stimulation, Self-direction, Universalism, Benevolence, Tradition, Conformity, Security, and Spirituality. These value types, according to Schwartz (1992) can be divided into two categories, which are individual and collective. The value types that serve individual interests are achievement, power, hedonism, stimulation and self-direction. On the other hand, benevolence, tradition, and conformity values serve collective interests. The values, universalism and security, can be considered under those two categories (Figure 1).

\section{Self-Transcendence}

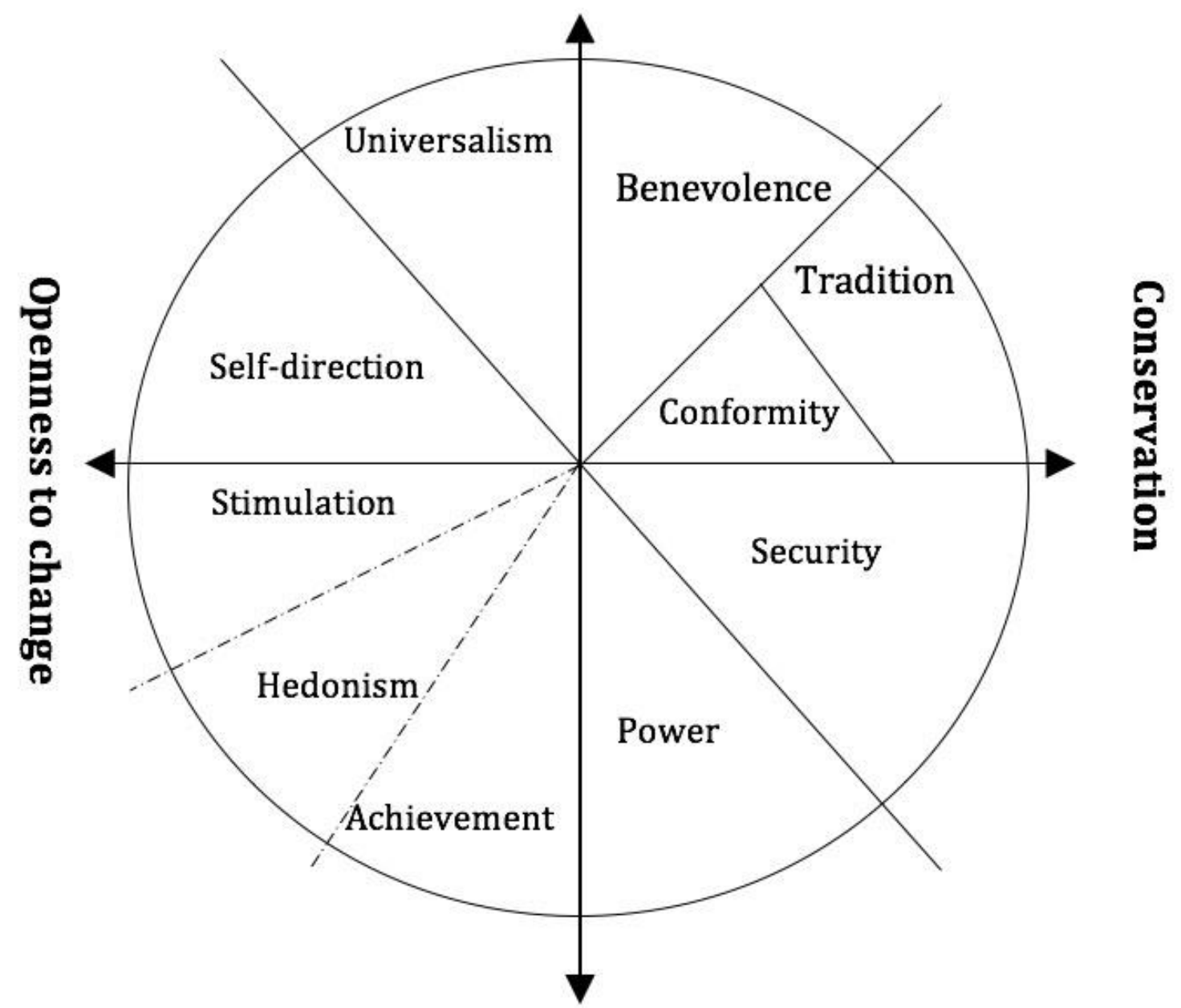

Self-Enhancement

Figure 1. Schwartz's model of motivational types of values (Schwartz, 1992)

Higher education institutions are regarded as places where "leaders of the future" () get education to fulfill the needs for global citizenship that will in turn allow the nations to overcome the challenges they face in global world (Jarrar, 2012). In this sense, those institutions are expected to prepare younger generations to get involved in civic life in 
local and global areas (Evans, 2006). At this point, the term 'global citizenship' gains importance since universities are institutions that are not purely local and have international connections. Schattle (2009) has mentioned three ideas in his study regarding global citizenship which are responsibility, awareness and engagement. In this respect, global citizenship is considered to include three dimensions that are social responsibility, global civic engagement and global competence (Morais \& Ogden, 2011).

In the literature, social responsibility is regarded as level of social concern to others including one's society and environment. The members who have social responsibility are generally respectful to different cultures (Braskamp, Braskamp, and Merrill, 2008). Social responsibility is also defined as one of the major purposes of universities while teaching citizenship values (Unesco, 2009). On the other hand, global competence is defined as being open minded towards other cultures and differences by being able to criticize and think without having ethnocentricity in evaluating others (American Council on Education, 2008). The last dimension of global citizenship, the global civic engagement, is defined as being aware of the local and global problems and responding those problems by actively participating in community and political live voluntarily (Deardorff, 2006).

There have been various studies that examined how student values shape their experiences when they enter to college (e.g., Jones, 1997; Knox, Zusman, \& Cooper, 2001; McCollum, 2005; Miller \& Hardin, 2002; Verplanken \& Holland, 2002; Yeh, Carter, \& Pieterse, 2004). In most of those studies, the results show that while the values that students keep shape their experiences during the college, the institutions' approaches towards certain values might cause changes in students' behavior. Further longitudinal studies might be considered on to make a comparison about whether citizenship perceptions of university students change or not after they graduate.

\section{Method and Data}

The present research is a quantitative study. It is a descriptive study that seeks to describe the 'citizenship' phenomenon by analyzing the answers of university students to the question 'what does citizenship mean for you?'. Among the choices are the single value items included in the Schwartz (1992) value survey (SVS) that are equality, freedom, social order, national security, a world at peace, respect for tradition, respect for privacy, social justice, independent, protecting the environment, loyalty, obedient, helpful, and responsible. The researcher tries to give a description of how students perceive these single value items with respect to citizenship. The Turkish version of SVS was adapted into Turkish language by Kusdil and Kagitcibasi (2000). The reliabilities for the adapted SVS ranges from .51 to .77 . The reliability coefficients for each value item was reported as follows: Benevolence .76, universalism .77 , hedonism.54, power .75 , achievement .66, stimulation .70 , self-direction .69 , tradition .63 , conformity .51 and security .59 (Kusdil and Kagitcibasi 2000).

The Likert scale was administered to a sample of 280 students randomly drawn from first year and last year students of two universities in Istanbul. Likert scales are important in revealing the perceptions of participants on specific subjects. Students were asked to describe the meaning of citizenship by selecting the options given by the researcher. The respondents rated the importance of each of the items on a 7-point scale ranging from 'not at all important' (1) to 'extremely important' (7). The results were analyzed using SPSS 20 software in order to implement a descriptive analysis. The mean age of the participants is 19.91 with a standard deviation of 2.086 . While $58.3 \%$ of the participants are female, the remaining $41.3 \%$ are male students. The $59.4 \%$ of the students were in their first year of study while the remaining $40.6 \%$ were reported as the last year students. In the data analysis, the mean score of the entire sample on each value item was determined. This analysis was implemented also for males and female participants separately looking at the mean score and standard deviation of each single value item.

\section{Results}

When one looks at university students' values and their perceptions about citizenship, it should be considered and kept in mind that students from different departments might have different value priorities that might cause different citizenship perceptions. In this sense, Verkasalo, Daun and Niit (1994) have looked at the value priorities of students from business, technology, and humanities and social science students in Estonia, Finland, and Sweden. The findings of that study show us that each department has its own student profiles that care about different types of values. While business school students scored high on achievement and power type values, students of social science and humanities departments scored higher on universalism and spirituality values. On the other hand, technology students scored higher on security values.

The results of the study suggest that the students in the faculty of humanities and social sciences (HSS) favor equality $(s=1.117)$, freedom $(s=1.271)$, social order $(s=1.255)$, a world at peace $(s=1.184)$, social justice $(s=1.144)$, being independent $(s=1.304)$, and protecting the environment $(s=1.363)$ compared to the students in the faculty of 
management and administrative sciences. On the other hand, the students in the faculty of management and administrative sciences (MAS) favor the single value items national security $(s=1.296)$, respect for tradition $(s=1.303)$, loyalty $(s=1.096)$, being obedient $(s=1.307)$, being helpful $(s=1.198)$ and being responsible $(s=1.040)$. In this sense, it might be claimed that the students of humanities and social sciences have more individualistic values whereas the ones in the faculty of management and administrative sciences show the characteristic feature of collectivistic societies. In other words, the HSS students are more inclined towards valuing individual freedom in terms of citizenship while the MAS students are more obedient and traditional while defining citizenship.

One can also think about gender differences in value priorities while analyzing values and their effects on citizenship perceptions. As Smith and Schwartz (1997) report, power and achievement values are more important for men while benevolence values were mostly prioritized by females compared to men. There are also some studies (Verkasalo, et al., 1994; Verkasalo, Tuomivaara, \& Lindeman 1996) talking about the reality of gender differences in prioritizing values. The findings of our study did not confirm the mentioned studies in this area. The descriptive analysis of the data reveals that females highly prioritize all single value items compared to males, which are equality $(s=1.115)$, social order $(s=1.141)$, national security $(s=1.204)$, a world at peace $(s=1.151)$, respect for tradition $(s=1.255)$, respect for privacy $(s=.945)$, social justice $(s=1.120)$, being independent $(s=1.120)$, protecting the environment $(s=1.259)$, loyalty $(s=1.059)$, being obedient $(s=1.295)$, being helpful $(s=1.136)$, and being responsible $(s=1.045)$. All the single value items are more valued by female participants compared to the males.

\section{Discussion and Conclusion}

The literature review shows that there has been conducted numerous studies about values but there is a lack of research on specifically value priorities on citizenship perceptions. In this sense, this study is believed to fill a gap in literature that takes values and citizenship into account in the same context.

In todays' world, the borders of nations are vaguer compared to several decades ago. The term 'world citizenship' (Heater, 2004) becomes an alternative for the societies having many cultures and national at once. In such an environment, educational institutions become more important in shaping the perception of 'citizenship' since the graduates of those institutions will shape the future world. In this sense, it would be marvelous if we had a similar study in Turkey two decades ago. The results would give us a chance to compare the value priorities and citizenship perceptions of university students in Turkey in 1980s to the current students. In this sense, this study might have an important place in literature for the future studies. We should know how the Turkish universities shape the students' perception of citizenship in order to make a claim about whether they have any role or not. However, the current study reveals that the university students participated in the study show a tendency towards having more individualistic values which is similar to the current state in most developed nations.

Citizenship perceptions are essential parts of having a peaceful or an uneasy society. Especially in our modernized and globalized world, it is a decisive mean in daily life while establishing relationship with others. The culture of a person where he lives in plays a key role in determining the values of a person (Lafer, 2014). The Eastern and Western cultures differ in that sense. The core values that differentiate between these two cultures are individualism and collectivism. The differences of those values are so clear that they shape not only individuals' life but also societies. For example, while marriage in western cultures is regarded as the union of two individuals, it is seen as relationship between two families in eastern cultures. Turkey is one of those countries that is categorized as a collectivistic nation. However, the study reveals that the university students participated in the study show tendency towards values prioritized in individualistic nations. Further studies need to be conducted in order to determine whether there has been a shift in this sense for the Turkish society.

\section{References}

Aisen, A., \& Veiga, F. J. (2013). How does political instability affect economic growth?. European Journal of Political Economy, 29, 151-167. http://dx.doi.org/10.1016/j.ejpoleco.2012.11.001

American Council on Education. (2008). Global learning for all. Retrieved from http://www.acenet.edu

Aydin, H. (2013). A Literature-based Approaches on Multicultural Education. The Anthropologist, 16(1-2), 31-44.

Aydin, H. \& Tonbuloglu, B. (2014). Graduate students perceptions? on multicultural education: a qualitative case study. Eurasian Journal of Educational Research, 57, 29-50. http://dx.doi.org/10.14689/ejer.2014.57.3

Barrett, D. (1961). Values in America. Notre Dame: University of Notre Dame Press. 
Hicks, M. (2006). Our underachieving colleges: A Candid look at how much students learn and why they should be learning more. International Journal of Educational Advancement, 6(4), 321-323. http://dx.doi.org/10.1057/palgrave.ijea.2150040

Bond, E.J. (1983). Reason and value. Cambridge: Cambridge University Press.

Braskamp, L. A, Braskamp, D.C. \& Merrill, K.C. (2008). Global Perspective Inventory (GPI); Its purpose, construction, potential uses, and psychometric characteristics. Chicago: Global Perspective Institute.

Deardorff, D. K. (2006). The identification and assessment of intercultural competence as a student outcome of internationalization. Journal of Studies in International Education, 10(3), 241-266. http://dx.doi.org/10.1177/1028315306287002

Evans, M. (2006). Educating for Citizenship: What teacher say and what teacher do. Canadian Journal of Education 29(2), 410-435. http://dx.doi.org/10.2307/20054170

Feather, N. T. (1995). Values, valences, and choice: The influence of values on the perceived attractiveness and choice of alternatives. Journal of Personality and Social Psychology, 68(6), 1135-1151. http://dx.doi.org/10.1037/0022-3514.68.6.1135

Fowers, B.J., \& Richardson, F.C. (1996). Why is multiculturalism good? American Psychologist, 51(6), 609-621. http://dx.doi.org/10.1037/0003-066x.51.6.609

Heater, D. (2013). What is citizenship. John Wiley \& Sons.

Heater, D. (2004). World citizenship: Cosmopolitan thinking and its opponents. Bloomsbury Publishing.

Jarrar, A.G. (2012). Global citizenship education in Jordania universities. Procedia-Social and Behavioral Sciences 47, 1922-1926. http://dx.doi.org/10.1016/j.sbspro.2012.06.924

Jones, S. R. (1997). Voices of identity and difference: A qualitative exploration of the multiple dimensions of identity development in women college students. Journal of College Student Development, 38, 376-386.

Karatas, K. \& Oral, B. (2015). Teachers' Perceptions on Culturally Responsiveness in Education. Journal of Ethnic and Cultural Studies, 2(2), 47-57.

Kaya, Y. (2015). Teachers' Perceptions on Culturally Responsiveness in Education. Journal of Ethnic and Cultural Studies, 2(2), 33-46.

Knox, D., Zusman, M. E., \& Cooper, C. (2001). Sexual values of college students. College Student Journal, 35, 24-27.

Kusdil, M.E. \& C. Kagitcibasi. (2000). Values tendency of Turkish teachers and Schwartz theory of values. Turkish Journal of Psychology, 15(45), 59-76.

Lafer, S. (2014). Democratic Design for the Humanization of Education. Journal of Ethnic and Cultural Studies, 1(1), 6-12.

McCollum, D. L. (2005). What are the social values of college students? A social goals approach. Journal of College and Character, 6(6), 1-21. http://dx.doi.org/10.2202/1940-1639.1469

Miller, M. L., \& Hardin, S. I. (2002). Relations among and between career values and Christian religious values. Counseling \& Values, 46(2), 96-107. http://dx.doi.org/10.1002/j.2161-007x.2002.tb00280.x

Morais, D. B \& Ogden, A.C. (2011). Initial Development and Validation of the Global Citizenship Scale. Journal of Studies in International Education, 15(5), 445-466. http://dx.doi.org/10.1177/1028315310375308

Rokeach, M. (1968). Beliefs, Attitudes, and Values. San Francisco: Jossey Bass

Sagiv, L., \& Schwartz, S. H. (1995). Value priorities and readiness for out-group social contact. Journal of Personality and Social Psychology, 69, 437-448. http://dx.doi.org/10.1037/0022-3514.69.3.437

Schattle, H. (2009). Global citizenship in theory and practice. In R.Lewin (Ed.). The handbook of practice and research in study abroad: Higher education and the quest for global citizenship. New York: Routledge.

Scott, E. D. (2000). Moral values: Situationally defined individual differences. Business Ethics Quarterly, 10(2), 497-521. http://dx.doi.org/10.2307/3857888 
Schwartz, S. H. (1992). Universals in the content and structure of values: Theoretical advances and empirical tests in 20 countries. Advances in experimental social psychology, 25, 1-65. http://dx.doi.org/10.1016/s0065-2601(08)60281-6

Smith, P.B. \& Schwartz, S.H. (1997). Values, in: J.W. Berry, M.H. Segall \& C. Kagitcibasi (Eds) Handbook of cross-cultural psychology, 3(2), 75-118. Boston Allyn \& Bacon.

UNESCO. (2009). The new dynamics of higher education and research for societal change and development. Paris: UNESCO.

Verkasalo, M., Daun, A. \& Niit, T. (1994). Universal values in Estonia, Finland and Sweden. Ethnologia Europaea, 24, 101-117.

Verkasalo, M., Tuomivaara, P. \& Lindeman, M. (1996). 15-year-old pupils' and their teachers' values, and their beliefs about the values of an ideal pupil. Educational Psychology, 16(1), 35-47. http://dx.doi.org/10.1080/0144341960160103

Verplanken, B., \& Holland, R. W. (2002). Motivated decision making: Effect of activation and self-centrality of values on choices and behavior. Journal of Personality and Social Psychology, 82(3), 434-447. http://dx.doi.org/10.1037//0022-3514.82.3.434

Yeh, C. J., Carter, R. T., \& Pieterse, A. L. (2004). Cultural values and racial attitudes among Asian American students. An exploratory investigation. Counseling \& Values, 48(2), 82-95. http://dx.doi.org/10.1002/j.2161-007x.2004.tb00235.x 